\title{
About the Power Generation Confirmation of the Induction Motor and the Influence on the Islanding Detection Device
}

\author{
Hironobu Igarashi Member (Japan Electrical Safety \& Environment Technology Laboratories) \\ Takashi Sato Non-member (Japan Electrical Safety \& Environment Technology Laboratories) \\ Kazunori Miyamoto Student Member (Tokyo University of Agriculture and Technology) \\ Kousuke Kurokawa Member (Tokyo University of Agriculture and Technology)
}

Keywords: photovoltaic system, induction motor, islanding detection device, islanding, generator

The photovoltaic generation system must have protection device and islanding detection devices to connect with utility line of the electric power company. It is regulated in the technological requirement guideline and the electric equipment technology standard that the country provides. The islanding detection device detected purpose install for blackout due to the accident occurrence of the earth fault and the short-circuit in the utility line.

When the islanding detection device detects the power blackout, it is necessary to stop the photovoltaic generation system immediately. If the photovoltaic generation system is not stopped immediately,electricity comes to charge the utility power line very at risk. But. we had already known that the islanding detection device can't detect the islanding phenomenon, if is there the induction motor in the loads.

Authors decided to investigate the influence that the induction motor gave to the islanding detection device. Two causes to which the induction motors continues the islanding are thought. When the frequency decreases after the supply of electric power line stops, a synchronous speed of the induction motors decreases, the rotator with the inertia energy maintains the rotational speed, and the state of the dynamo and the state are thought to be changeable from the state of the induction motors. It is thought that it has the action to which the voltage decrease is controlled in addition by supplying active power when the induction motors exists from these as a load of the distribution line. It is thought that the induction motors is a load in which the individual operation is continued easily from the geostationary type load by these characteristic changes. Secondary, the constant of the induction motors usually has rated frequency $\mathrm{f}$ design. The frequency becomes $\mathrm{f}^{\prime}$ when changing $\mathrm{f}^{\prime} / \mathrm{f}=\alpha$ time. Therefore, reactance is changed depending on the changing frequency and the amount of a reactive power will change, too. Therefore, it is possible that the induction motors has the action that makes amends for the reactive power according to the change in frequency.

We confirmed validity from the result of the experiment by using PCS in which the above-mentioned event was marketed.

We confirmed the induction motors was changed into the dynamo by the experiment result. The induction motors and the resistance load are connected in parallel and the power generation confirm method of the induction motors is cut off from the power supply. And, slipping was calculated from a rotational speed and a synchronous speed of the induction motors after it had cut off the power supply. The calculation result of showing in Fig. 1 is a result of confirming slip less than 0 . Therefore, it was clarified to have changed the induction motors into the dynamo. The induction motor change to generator that the load condition is restraining voltage. Moreover, it was clarified that the time of the islanding continuance was long

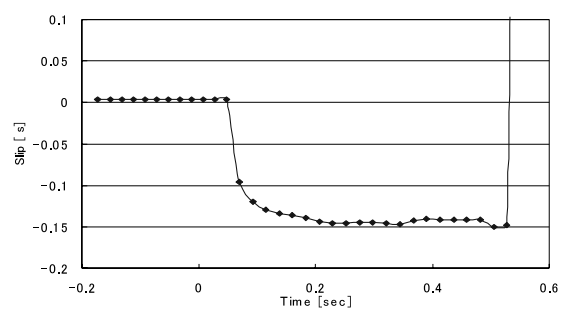

Fig. 1. Calculation result at slip

Table 1. Inductance value change table of induction motors

Upper row (Before cut out utility line) The lower $(0.3$ seconds after cut out utility line $)$

\begin{tabular}{|c|c|c|c|c|c|c|}
\hline \multirow{2}{*}{\multicolumn{2}{|c|}{$\begin{array}{l}\text { Reactive power } \\
\text { (Var) }\end{array}$}} & \multicolumn{5}{|c|}{ Active power (W) } \\
\hline & & \multirow{2}{*}{$\begin{array}{l}-10 \% \\
114 \mathrm{mH} \\
\end{array}$} & \multirow{2}{*}{$\begin{array}{c}-5 \% \\
114 \mathrm{mH} \\
\end{array}$} & \multirow{2}{*}{$\begin{array}{c}0 \% \\
114 \mathrm{mH} \\
\end{array}$} & \multirow{2}{*}{$\begin{array}{c}+5 \% \\
115 \mathrm{mH} \\
\end{array}$} & \multirow{2}{*}{$\begin{array}{l}+10 \% \\
116 \mathrm{mH} \\
\end{array}$} \\
\hline$-10 \%$ & $\begin{array}{c}\text { Normal } \\
\text { operation }\end{array}$ & & & & & \\
\hline$-10 / 0$ & $\begin{array}{c}0.3 \text { secon- } \\
\text { ds after }\end{array}$ & $44 \mathrm{mH}$ & $54 \mathrm{mH}$ & $84 \mathrm{mH}$ & $90 \mathrm{mH}$ & $84 \mathrm{mH}$ \\
\hline \multirow{2}{*}{$-5 \%$} & $\begin{array}{l}\text { Normal } \\
\text { operation }\end{array}$ & $114 \mathrm{mH}$ & $115 \mathrm{mH}$ & $114 \mathrm{mH}$ & $115 \mathrm{mH}$ & $114 \mathrm{mH}$ \\
\hline & $\begin{array}{c}0.3 \text { secon- } \\
\text { ds after }\end{array}$ & $60 \mathrm{mH}$ & $115 \mathrm{mH}$ & $94 \mathrm{mH}$ & $104 \mathrm{mH}$ & $103 \mathrm{mH}$ \\
\hline \multirow{2}{*}{$0 \%$} & $\begin{array}{c}\text { Normal } \\
\text { operation }\end{array}$ & $114 \mathrm{mH}$ & $114 \mathrm{mH}$ & $114 \mathrm{mH}$ & $115 \mathrm{mH}$ & $116 \mathrm{mH}$ \\
\hline & $\begin{array}{c}0.3 \text { secon- } \\
\text { ds after }\end{array}$ & $50 \mathrm{mH}$ & $95 \mathrm{mH}$ & $117 \mathrm{mH}$ & $128 \mathrm{mH}$ & $116 \mathrm{mH}$ \\
\hline \multirow{2}{*}{$+5 \%$} & $\begin{array}{c}\text { Normal } \\
\text { operation }\end{array}$ & $116 \mathrm{mH}$ & $114 \mathrm{mH}$ & $114 \mathrm{mH}$ & $114 \mathrm{mH}$ & $115 \mathrm{mH}$ \\
\hline & $\begin{array}{c}0.3 \mathrm{secon-}- \\
\text { ds after }\end{array}$ & $98 \mathrm{mH}$ & $136 \mathrm{mH}$ & $127 \mathrm{mH}$ & $118 \mathrm{mH}$ & $154 \mathrm{mH}$ \\
\hline \multirow{2}{*}{$+10 \%$} & $\begin{array}{c}\text { Normal } \\
\text { operation }\end{array}$ & $113 \mathrm{mH}$ & $114 \mathrm{mH}$ & $114 \mathrm{mH}$ & $115 \mathrm{mH}$ & $114 \mathrm{mH}$ \\
\hline & $\begin{array}{c}0.3 \text { secon- } \\
\text { ds after }\end{array}$ & $79 \mathrm{mH}$ & $85 \mathrm{mH}$ & $84 \mathrm{mH}$ & $95 \mathrm{mH}$ & $50 \mathrm{mH}$ \\
\hline
\end{tabular}

compared with the load condition of not changing into the state of the generator.

Next, whether the inductance of the induction motors had changed from the islanding experiment from Table 1 was verified.

The value changes into the reactance of the induction motors according to the frequency change after the supply of electric power line stops. The frequency after the supply of electric power line stops changes for the unbalance the reactive power by the effect of the power rate constancy control with PLL of the power conditioner. However, induction motors also change frequency, makes amends for the amount of reactive power, and the change in the frequency after the supply of electric power line stops as a result is controlled. When the frequency changed after the supply of electric power line stopped, it was clarified of the action on the direction where it made amends from the change of the constant for the amount of reactive power, and the possession of the characteristic in which the continuance of the individual operation was promoted. 


\title{
誘導電動機の発電確認と単独運転検出装置への影響について
}

\author{
正 員 五十嵐広宣*,** 非会員 佐藤 孝則* \\ 学生員 宮本 和典** 正 員 黒川 浩助**
}

\begin{abstract}
About the Power Generation Confirmation of the Induction Motor and the Influence on the Islanding Detection Device
\end{abstract}

Hironobu Igarashi*,**, Member, Takashi Sato*, Non-member, Kazunori Miyamoto**, Student Member, Kousuke Kurokawa**, Member

The photovoltaic generation system must have protection device and islanding detection devices to connect with utility line of the electric power company. It is regulated in the technological requirement guideline and the electric equipment technology standard that the country provides. The islanding detection device detected purpose install for blackout due to the accident occurrence of the earth fault and the short-circuit in the utility line. When the islanding detection device detects the power blackout, it is necessary to stop the photovoltaic generation system immediately. If the photovoltaic generation system is not stopped immediately, electricity comes to charge the utility power line very at risk. We had already known that the islanding detection device can't detect the islanding phenomenon, if is there the induction motor in the loads. Authors decided to investigate the influence that the induction motors gave to the islanding detection device. The result was the load condition that the induction motors changed generator the voltage is restraining. Moreover, it was clarified that the time of the islanding was long compared with the load condition of not changing into the state of the generator. The value changes into the reactance of the induction motors according to the frequency change after the supply of electric power line stops. The frequency after the supply of electric power line stops changes for the unbalance the reactive power by the effect of the power rate constancy control with PLL of the power conditioner. However, the induction motors is also to the changing frequency, makes amends for the amount of reactive power, and the change in the frequency after the supply of electric power line stops as a result is controlled. When the frequency changed after the supply of electric power line stopped, it was clarified of the action on the direction where it made amends from the change of the constant for the amount of an invalid electric power, and the possession of the characteristic in which the continuance of the individual operation was promoted.

キーワード : 太陽光発電システム, 誘導電動機, 単独運転検出装置, 単独運転, 発電機

Keywords: photovoltaic system, induction motor, islanding detection device, islanding, generator

1. はじめに

太陽光発電システムなどの分散型発電システムは, 電力 会社などの配電線に連系運転を行う際に, 配電線における 電力品質や安全確保の面から，電気設備の技術基準 ${ }^{(1)}$, 電 力品質確保に係わる系統連系技術要件ガイドライン (2) 及び

\footnotetext{
* (財) 電気安全環境研究所

于 151-8545 東京都渋谷区代々木 5-14-12

Japan Electrical Safety \& Environment Technology Laboratories

5-14-12, Yoyogi, Shibuya-ku, Tokyo 151-8545

** 国立大学法人東京農工大学工学府電子情報工学専攻

厂 184-8588 小金井市中町 2-24-16

Tokyo University of Agriculture and Technology

2-24-16, Naka-cho, Koganei 184-8588
}

系統連系規程 ${ }^{(3)}$ によって定められた単独運転検出装置など の保護装置を具備することが求められている。

この単独運転検出装置は, 系統連系を行っている配電線 において，地絡や短絡事故等による配電線停止が発生した 場合に安全を確保するため, 同停止状態を速やかに検出し 太陽光発電システムなどを当該配電線から解列させ，配電 線への電力供給（逆充電）を停止させることを目的として いる。

単独運転検出装置の機能を試験評価する場合は, 安全性 を保証する上で実態に即した範囲内で最も単独運転現象が 継続し易い条件を考慮して設定する必要がある。すなわち, 一般の誘導性負荷と力率改善用コンデンサの容量性負荷を 組み合わせた共振負荷 ${ }^{(4)}$ や回転機負荷 ${ }^{(5)}$ などの配電線停止 
時に単独系の周波数や電圧を維持する特性を持つ回生負荷 を考慮する必要がある。

実際に共振負荷や回転機負荷などの回生エネルギーを持 つ負荷が配電線にある場合に，単独運転現象が継続するこ とが確認されている(6)(7)。また, 著者らは, 同じ回生エネル ギーを持つ共振負荷と回転機負荷を用い，単独運転検出装 置へ与える影響について比較試験を行い，共振負荷よりも 回転機負荷が，単独運転現象継続時間が長くなりより厳し い条件であることを明らかにした ${ }^{(8)}$ 。

回生負荷を用いた単独運転検出装置の標準的な試験方法 の検討は，財団法人電力中央研究所が新エネルギー・産業 技術総合開発機構から委託された研究開発事業 ${ }^{(9) \sim(14)}$ によ り実施された経緯がある。この中では， $10 \mathrm{~kW}$ 未満の住宅 用低圧系統連系太陽光発電用パワーコンディショナの単独 運転試験方法の負荷条件について検討を行い，(1実際に低 圧需要家で使用されている負荷の中で回生エネルギーが最 も大きい分類に属していること，(2)将来の認証制度におい て実用的なものや JIS 規格化への適用を配慮し, 比較的安 価で一般的に入手し易いこと，を同時に満たす負荷として，

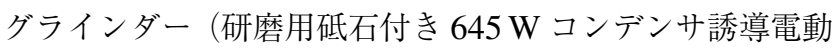
機）が採用された。これらの検討結果は, 財団法人電気安 全環境研究所 (JET) の認証試験方法 ${ }^{(15)}$ に反映された。

近年, 太陽光発電システムの世界的導入拡大により, IEC 規格 (16) などの国際規格化の動きが活発化しており，単独運 転検出装置の試験方法は，今後の改訂を含め国際規格への 反映が望まれている。この中では, 上記誘導電動機または, 本電動機の特性を標準化するための共通的なモデルを作成 する必要がある。このためには，同誘導電動機の単独運転 時の挙動を詳細に解明する必要があるが，これまでになさ れていない。

今回, 著者らは, 単独運転検出装置の評価手法用として 用いられている誘導電動機について, 配電線から切り離さ れた後の挙動に着目し, 誘導電動機の挙動及びその挙動が 単独運転検出装置へどのような影響を与えているのかを検 証した。

\section{2. 系統連系形太陽光発電システム用パワーコンディ ショナの単独運転時の運転特性}

〈2・1〉太陽光発電システム用パワーコンディショナの 制御方式 太陽光発電システム用パワーコンディショナ （PCS）は，常に変化する気象条件でも太陽光電池の発電電 力を配電線に効率良く出力する必要がある。そのため, PCS は, 最大電力追従制御（MPPT 制御）により出力電力值を 太陽電池出力に応じて制御しながら, 出力損失や配電線損 失を軽減するために無効電力の発生を抑え運転を行うこと が要求されおり，これらの運転条件を満たす制御方法とし て電圧型電流制御方式を多くの機種が採用している。

電圧型電流制御方式は，系統電圧の周波数及び位相に一 致するよう PLL 制御回路（位相同期回路）によって出力電 流を直接制御し, 力率 1 での運転を行うものである。また,
同時に負荷の急峻な変動にも強く，配電線の短絡時におい ても瞬時に電流を制御できることから, 安全性及び電力品 質の面で優れており, 電力品質確保に係わる系統連系技術 要件ガイドラインにおいても推奨されている。

\section{$\langle\mathbf{2} \cdot \mathbf{2}\rangle$ 配電線停止後の周波数・電圧変化に与える影響}

電圧型電流制御方式の PCS は, PLL 制御回路によって, 基本的に力率が一定（通常は 1) となるように, 出力電流 の周波数及び位相を制御している。配電線停止直前に, 特 に発電量と負荷量の間の無効電力が不平衡状態にある場合 は, 配電線停止直後に一時的に不平衡分を PCS が賄うこと になる。この結果，上記の力率一定制御により出力電流位 相を変化させ力率を戻そうとするが, 系統電圧が存在しな いため, 電流位相の変化とともに電圧位相も変化し, 結果 的に周波数の変化を招くこととなる。

電圧については, 有効電力の不平衡度の影響を特に受け, 単独運転後, 基本的には負荷の抵抗分と MPPT 制御による 出力電力一定の条件により定まる電圧值に変化する。

\section{3. 考えられる単独運転時における誘導電動機の 特性変化}

誘導電動機の定数は, 通常定格周波数 $f$ にて設計されて おり，周波数が $f^{\prime}$ のように変化した場合には $f^{\prime} / f=\alpha$ 倍 となる ${ }^{(17)}$ 。そのため, 変化する周波数によってリアクタン スが変化し無効電力量も変化することになる。したがって, 誘導電動機は, 周波数の変化によっては, 無効電力を補償 する作用をもつことが考えられる。

配電線停止後に周波数が低下した場合は, 誘導電動機の 同期速度が低下し，慣性エネルギーを持った回転子が回転 数を維持することにより, 誘導電動機状態から発電機状態 へと状態を変化するものと考えられる。これらから誘導電 動機が配電線の負荷として存在する場合には，更に有効電 力の供給により電圧低下を抑制する作用も持つものと考え られる。これらの特性変化により, 誘導電動機は, 共振負 荷などの静止形負荷よりも単独運転を継続させ易い負荷で あることが考えられる。

以上の考察の妥当性について，実験により検証した。

\section{4. 誘導電動機の在否と単独運転継続時間の関連}

〈4・1〉誘導電動機の在否による単独運転現象継続の検 証単独運転現象の継続時間は, 誘導電動機が負荷とし て存在する場合に長くなる傾向にある ${ }^{(6)}$ 。誘導電動機が負 荷として接続されている場合の影響について, 誘導電動機 の在否により検証を行った。

単独運転継続時間の計測は，図 1 に示す JET 認証試験方 法 ${ }^{(15)}$ 及び IEC 規格 (16) において採用されている一般住宅用 太陽光発電システムが配電線に連系運転している状態をモ デル化した回路を用いて行った。

実験に用いたPCS は，市場で多く使用されている定格 出力 $4[\mathrm{~kW}]$ モデルを用いた。保護継電器の設定值は, 工 場出荷時整定值（過電圧検出值 $115.0[\mathrm{~V}]$, 不足電圧検出 
值 85.0 [V], 過周波数検出值 $51.0[\mathrm{~Hz}]$, 不足周波数検出值 $48.5[\mathrm{~Hz}]$ ）とした。また，単独運転検出装置の受動的及び 能動的検出装置については，配電線停止後の周波数などへ の影響を無くす目的からマスクした。

$\langle\mathbf{4} \cdot \mathbf{2}\rangle$ 単独運転試験用誘導電動機の概要 単独運転 継続時間の計測に用いられている誘導電動機は，一般に市 販されているグラインダーと言われる機器である。通常グ ラインダーは, 誘導電動機のシャフト部分に研磨用の砥石 を固定し，高速回転している砥石部分に鉄等の切れ端部分 を当て，研磨を行う工作機器である。グラインダーの仕様 を表 1 に示す。

グラインダーを単独運転試験用の負荷として使用する場 合は, 空回転 (無負荷運転) 状態にて運転する。空回転と する理由は，砥石自身の重さと大きさによって定まる慣性 モーメントが運動エネルギーとして慣性負荷となり，配電 線停止後も回転を継続しエネルギーを放出すると考えられ ているからである。

$\langle\mathbf{4} \cdot \mathbf{3}\rangle$ 単独運転継続時間の計測方法 単独運転継続 時間の計測方法は, 図 1 に示す負荷 $\left(R_{A S C}\right)$ が接続されて いる箇所を潮流点とし，潮流点の有効及び無効電力を $\mathrm{We} 2$ 及びWr2によって計測し，順潮流及び遅れをプラスとし逆 潮流及び進みをマイナスとし以下に示す手順にて行った。

(1) PCS は, 定格電圧 $200[\mathrm{~V}]$, 定格周波数 $50[\mathrm{~Hz}]$ にて, 定格出力状態の $4[\mathrm{~kW}]$ となるよう運転を行う。

(2) 潮流点の有効電力は, PCS の定格出力に対して $-10 \%$ $(-400 \mathrm{~W}),-5 \%(-200 \mathrm{~W}), 0 \%(0 \mathrm{~W}),+5 \%(200 \mathrm{~W})$, $+10 \%(400 \mathrm{~W})$ となるよう抵抗負荷の調整を行った。

(3) 潮流点の無効電力は, PCS の定格出力に対して, $-10 \%$ (-400 Var), $-5 \%$ (-200 Var), 0\% (0 Var) と

表 1 グラインダーの仕様

Table 1. Specification of grinder.

\begin{tabular}{|c|c|c|c|}
\hline Electric ratings & $\begin{array}{c}\text { Size of motor } \\
\mathrm{W}[\mathrm{m}] \times \mathrm{H}[\mathrm{m}]\end{array}$ & $\begin{array}{l}\text { The size of the } \\
\text { Flywheel } \\
\text { D[m]W[kg] }\end{array}$ & $\begin{array}{c}\text { Moment of } \\
\text { inertia } \\
{\left[\mathrm{kg} \cdot \mathrm{m}^{2}\right]}\end{array}$ \\
\hline $\begin{array}{c}1 \Phi 100 \mathrm{~V}, 6.5 \mathrm{~A}, \\
\text { 2pole type } \\
50 / 60 \mathrm{~Hz} \\
2960 / 3560 \mathrm{rpm} \\
\text { Output power } \\
645 \mathrm{~W} \\
\end{array}$ & $\begin{array}{l}\text { W:0.452 } \\
\text { H:0.267 }\end{array}$ & $\begin{array}{l}\text { D: } 0.205 \times 2 \\
\text { W: } 1.300 \times 2\end{array}$ & 0.015 \\
\hline
\end{tabular}

なるように容量性負荷を調整する。また，無効電力量 を+5\% (200 Var)，+10（400 Var）に調整する場合は， 誘導性負荷を調整する。

(4) 単独運転継続時間の計測は, $t=0$ の夕イミングで 開閉器 $\mathrm{SW}_{C B}$ を開放し，PCS のゲートブロック信号 及び解列信号 (開閉器解列信号) が出力されるまでの $\Delta X[\mathrm{Sec}]$ について測定を行う。

$\langle\mathbf{4} \cdot \mathbf{4}\rangle$ 単独運転継続時間の計測結果 誘導電動機を 接続しない状態の単独運転継続時間結果を表 2 上段に示し, 誘導電動機を接続した状態の単独運継続時間結果を表 2 の 中段に示す。また，表 2 中段の誘導電動機がある状態の単 独運転継続時間から表 2 上段誘導電動機が無い状態での単

表 2 誘導電動機在否による単独運転継続時間

Table 2. Islanding continuance time when with or without Induction motors.

\begin{tabular}{|c|c|c|c|c|c|c|}
\hline \multirow{2}{*}{\multicolumn{2}{|c|}{ Reactive power (Var) }} & \multicolumn{5}{|c|}{ Active power (W) } \\
\hline & & \multirow{2}{*}{$\begin{array}{l}-10 \% \\
550 \mathrm{~ms}\end{array}$} & \multirow{2}{*}{$\begin{array}{c}-5 \% \\
579 \mathrm{~ms}\end{array}$} & \multirow{2}{*}{$\begin{array}{c}0 \% \\
550 \mathrm{~ms}\end{array}$} & \multirow{2}{*}{$\begin{array}{l}+5 \% \\
564 \mathrm{~ms}\end{array}$} & \multirow{2}{*}{$\begin{array}{c}+10 \% \\
558 \mathrm{~ms}\end{array}$} \\
\hline \multirow{3}{*}{$-10 \%$} & $\begin{array}{c}\text { Without } \\
\text { Induction } \\
\text { motor }\end{array}$ & & & & & \\
\hline & $\begin{array}{c}\text { With } \\
\text { Induction } \\
\text { motor }\end{array}$ & $659 \mathrm{~ms}$ & $650 \mathrm{~ms}$ & $611 \mathrm{~ms}$ & $617 \mathrm{~ms}$ & $591 \mathrm{~ms}$ \\
\hline & Differences & $109 \mathrm{~ms}$ & $71 \mathrm{~ms}$ & $61 \mathrm{~ms}$ & $53 \mathrm{~ms}$ & $33 \mathrm{~ms}$ \\
\hline \multirow{3}{*}{$-5 \%$} & $\begin{array}{l}\text { Without } \\
\text { Induction } \\
\text { motor }\end{array}$ & $577 \mathrm{~ms}$ & $574 \mathrm{~ms}$ & $576 \mathrm{~ms}$ & $618 \mathrm{~ms}$ & $642 \mathrm{~ms}$ \\
\hline & $\begin{array}{l}\text { With } \\
\text { Induction } \\
\text { motor }\end{array}$ & Islanding & Islanding & Islanding & $793 \mathrm{~ms}$ & $689 \mathrm{~ms}$ \\
\hline & Differences & - & - & - & $175 \mathrm{~ms}$ & $47 \mathrm{~ms}$ \\
\hline \multirow{3}{*}{$0 \%$} & $\begin{array}{l}\text { Without } \\
\text { Induction } \\
\text { motor }\end{array}$ & $615 \mathrm{~ms}$ & $654 \mathrm{~ms}$ & $654 \mathrm{~ms}$ & $650 \mathrm{~ms}$ & $790 \mathrm{~ms}$ \\
\hline & $\begin{array}{c}\text { With } \\
\text { Induction } \\
\text { motor }\end{array}$ & $585 \mathrm{~ms}$ & Islanding & Islanding & Islanding & $742 \mathrm{~ms}$ \\
\hline & Differences & $-30 \mathrm{~ms}$ & - & - & - & $-48 m s$ \\
\hline \multirow{3}{*}{$+5 \%$} & $\begin{array}{l}\text { Without } \\
\text { Induction } \\
\text { motor }\end{array}$ & $569 \mathrm{~ms}$ & $584 \mathrm{~ms}$ & $592 \mathrm{~ms}$ & $600 \mathrm{~ms}$ & $564 \mathrm{~ms}$ \\
\hline & $\begin{array}{c}\text { With } \\
\text { Induction } \\
\text { motor }\end{array}$ & $578 \mathrm{~ms}$ & $673 \mathrm{~ms}$ & $867 \mathrm{~ms}$ & Islanding & Islanding \\
\hline & Differences & $9 \mathrm{~ms}$ & $89 \mathrm{~ms}$ & $275 \mathrm{~ms}$ & - & - \\
\hline \multirow{3}{*}{$+10 \%$} & $\begin{array}{l}\text { Without } \\
\text { Induction } \\
\text { motor }\end{array}$ & $576 \mathrm{~ms}$ & $541 \mathrm{~ms}$ & $564 \mathrm{~ms}$ & $569 \mathrm{~ms}$ & $548 \mathrm{~ms}$ \\
\hline & $\begin{array}{c}\text { With } \\
\text { Induction } \\
\text { motor }\end{array}$ & $552 \mathrm{~ms}$ & $585 \mathrm{~ms}$ & $591 \mathrm{~ms}$ & $584 \mathrm{~ms}$ & $587 \mathrm{~ms}$ \\
\hline & Differences & $-24 m s$ & $44 \mathrm{~ms}$ & $27 \mathrm{~ms}$ & $15 \mathrm{~ms}$ & $39 \mathrm{~ms}$ \\
\hline
\end{tabular}

Upper row (Without Induction motor), The middle (With Induction motor) The lower (Differences of the without Induction motor and with Induction motors)

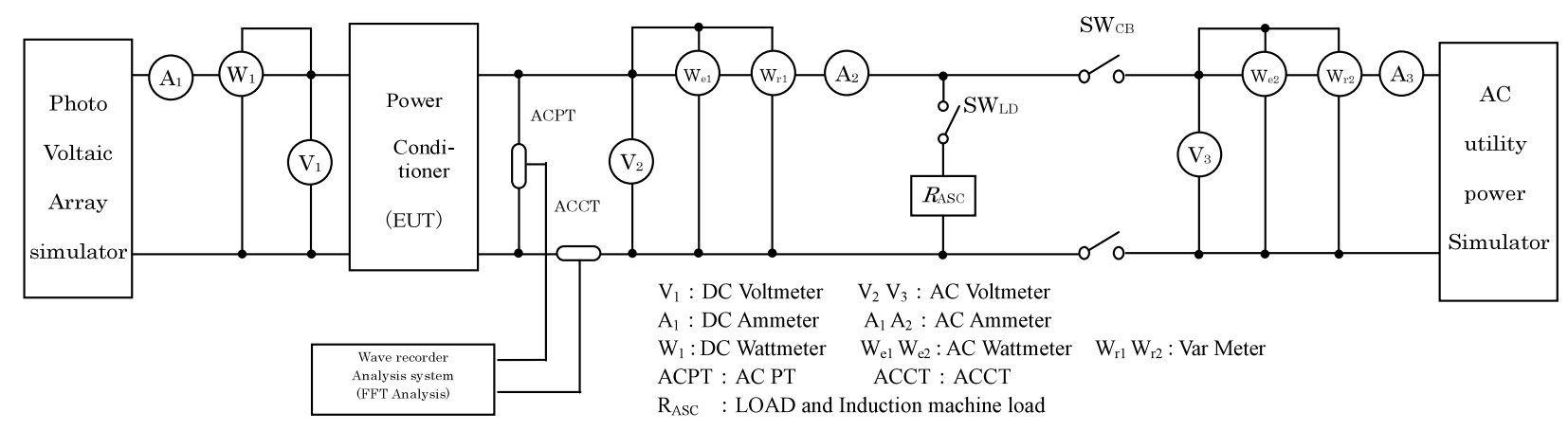

図 1 単独運転実験回路図

Fig. 1. The circuit of islanding tests. 
独運転継続時間を差し引いた時間を表 2 下段に示す。

誘導電動機がない状態での実験結果は，負荷条件に関係 なく配電線停止後から $600 \mathrm{mS}$ 前後で運転が停止している ことが確認できた。また，誘導電動機がある状態での実験 結果は，発電量と負荷量が平衡状態 $(\mathrm{P}=0 \%, \mathrm{Q}=0 \%)$ に ある負荷条件を中心に単独運転が 1 秒以上継続しているこ とが確認できた。なお，表 2 中の単独運転が 1 秒以上継続 している負荷条件については，単独運転として表記し，判 明し易くする目的でマーキングを行い，以降関連する表 3, 表 4, 表 5, 表 6 も同様に単独運転を 1 秒以上継続してい る負荷条件についてもマーキングを行った。

単独運転継続時間は，誘導電動機が負荷として存在する 場合に長くなる傾向にあるが，表 2 の下段に示すように一 部の負荷条件において誘導電動機がない方が単独運転の継 続時間が長いことが示された。この事象については，負荷 条件 $(\mathrm{P}=-10 \%, \mathrm{Q}=0 \%)$ を例に検証を行った。検証結果 は, 配電線停止後の周波数が過周波数継電器の検出值を超 えるまでの時間が，誘導電動機がある状態では 39.3 [ms], 誘導電動機がない状態では $78.9[\mathrm{~ms}]$ と差異があり, 配電線 停止後の周波数変化率の違いにより単独運転継続時間が短 くなったものと考えられる。

当該実験結果は，誘導電動機が負荷として存在する場合 に単独運転現象が長くなる傾向にあることが明らかになっ た。単独運転が継続する要因は，配電線停止後の電圧及び 周波数の変化が少ないことが考えられる。そのため，配電 線停止 0.3 秒後の電圧及び周波数について分析を行った。

$\langle\mathbf{4} \cdot \mathbf{5}\rangle$ 配電線停止後の周波数分析結果 誘導電動機 を接続しない状態での周波数分析結果は, 最大 $55.60[\mathrm{~Hz}]$, 最小 $44.42[\mathrm{~Hz}]$ と過不足周波数継電器の検出值を超過して いることが明らかになった。また，他の負荷条件すべてに おいても同様に継電器の検出值を超過していることが併せ て明らかになった。分析結果を表 3 の上段に示す。

誘導電動機を接続した状態での周波数分析結果は，最大 $54.01[\mathrm{~Hz}] ，$ 最小 $46.50[\mathrm{~Hz}]$ であり誘導電動機を接続しな い状態に比べ変化が少ないことが明らかになった。また， 単独運転が 1 秒以上継続している負荷条件の周波数変化は, 過不足周波数継電器の検出值以内で維持されていることが 併せて明らかになった。分析結果を表 3 の下段に示す。

$\langle\mathbf{4} \cdot \mathbf{6}\rangle$ 配電線停止後の電圧分析結果 誘導電動機在 否による電圧解析結果を表 4 に示す。表 4 の誘導電動機を 接続しない状態での電圧分析結果は，最大 220.02 [V]，最 小 $184.11[\mathrm{~V}]$ であった。また，誘導電動機を接続した状態 における電圧分析結果は，最大 229.80 [V]，最小 187.68 [V] で，いずれも過不足電圧継電器の検出閾值を超過している 值はないことが明らかになった。配電線停止後における電 圧值は，数箇所の負荷条件を除いて，誘導電動機を接続し た状態のほうが高くなることが明らかになった。

これらの結果から誘導電動機は, 周波数の変化の抑制と 電圧の低下を抑える効果があることを確認した。
表 3 誘導電動機在否による配電線停止 0.3 秒後 の周波数解析結果

Table 3. Frequency analysis result after 0.3 seconds after it blacks out when with or without Induction motor.

\begin{tabular}{|c|c|c|c|c|c|c|}
\hline \multirow{2}{*}{\multicolumn{2}{|c|}{$\begin{array}{l}\text { Reactive power } \\
\text { (Var) }\end{array}$}} & \multicolumn{5}{|c|}{ Active power (W) } \\
\hline & & \multirow{2}{*}{$\begin{array}{c}-10 \% \\
44.42 \mathrm{~Hz}\end{array}$} & \multirow{2}{*}{$\begin{array}{c}-5 \% \\
44.56 \mathrm{~Hz}\end{array}$} & \multirow{2}{*}{$\begin{array}{c}0 \% \\
44.48 \mathrm{~Hz}\end{array}$} & \multirow{2}{*}{$\begin{array}{c}+5 \% \\
44.59 \mathrm{~Hz}\end{array}$} & \multirow{2}{*}{$\begin{array}{c}+10 \% \\
44.67 \mathrm{~Hz}\end{array}$} \\
\hline \multirow{2}{*}{$-10 \%$} & $\begin{array}{l}\text { Without } \\
\text { Induction } \\
\text { motor }\end{array}$ & & & & & \\
\hline & $\begin{array}{c}\text { With } \\
\text { Induction } \\
\text { motor }\end{array}$ & $47.37 \mathrm{~Hz}$ & $47.28 \mathrm{~Hz}$ & $46.94 \mathrm{~Hz}$ & $46.82 \mathrm{~Hz}$ & $46.50 \mathrm{~Hz}$ \\
\hline \multirow{2}{*}{$-5 \%$} & $\begin{array}{c}\text { Without } \\
\text { Induction } \\
\text { motor }\end{array}$ & $44.92 \mathrm{~Hz}$ & $44.96 \mathrm{~Hz}$ & $45.02 \mathrm{~Hz}$ & $45.07 \mathrm{~Hz}$ & $45.06 \mathrm{~Hz}$ \\
\hline & $\begin{array}{c}\text { With } \\
\text { Induction } \\
\text { motor }\end{array}$ & $49.19 \mathrm{~Hz}$ & $48.52 \mathrm{~Hz}$ & $48.50 \mathrm{~Hz}$ & $48.49 \mathrm{~Hz}$ & $47.76 \mathrm{~Hz}$ \\
\hline \multirow{2}{*}{$0 \%$} & $\begin{array}{c}\text { Without } \\
\text { Induction } \\
\text { motor }\end{array}$ & $54.95 \mathrm{~Hz}$ & $46.03 \mathrm{~Hz}$ & $46.09 \mathrm{~Hz}$ & $46.15 \mathrm{~Hz}$ & $47.83 \mathrm{~Hz}$ \\
\hline & $\begin{array}{c}\text { With } \\
\text { Induction } \\
\text { motor }\end{array}$ & $52.14 \mathrm{~Hz}$ & $49.19 \mathrm{~Hz}$ & $50.90 \mathrm{~Hz}$ & $50.59 \mathrm{~Hz}$ & $47.94 \mathrm{~Hz}$ \\
\hline \multirow{2}{*}{$+5 \%$} & $\begin{array}{c}\text { Without } \\
\text { Induction } \\
\text { motor }\end{array}$ & $54.91 \mathrm{~Hz}$ & $55.27 \mathrm{~Hz}$ & $55.05 \mathrm{~Hz}$ & $54.54 \mathrm{~Hz}$ & $54.54 \mathrm{~Hz}$ \\
\hline & $\begin{array}{c}\text { With } \\
\text { Induction } \\
\text { motor }\end{array}$ & $52.23 \mathrm{~Hz}$ & $51.24 \mathrm{~Hz}$ & $50.89 \mathrm{~Hz}$ & $50.60 \mathrm{~Hz}$ & $50.58 \mathrm{~Hz}$ \\
\hline \multirow{2}{*}{$+10 \%$} & $\begin{array}{c}\text { Without } \\
\text { Induction } \\
\text { motor }\end{array}$ & $55.56 \mathrm{~Hz}$ & $55.57 \mathrm{~Hz}$ & $55.49 \mathrm{~Hz}$ & $55.60 \mathrm{~Hz}$ & $55.42 \mathrm{~Hz}$ \\
\hline & $\begin{array}{c}\text { With } \\
\text { Induction } \\
\text { motor }\end{array}$ & $54.01 \mathrm{~Hz}$ & $53.37 \mathrm{~Hz}$ & $52.88 \mathrm{~Hz}$ & $52.41 \mathrm{~Hz}$ & $53.02 \mathrm{~Hz}$ \\
\hline
\end{tabular}

Upper row (Without Induction motor), The lower (With Induction motor)

表 4 誘導電動機在否による配電線停止 0.3 秒後 の電圧解析結果

Table 4. Voltage analysis result after 0.3 seconds after it blacks out when with or without Induction motor.

\begin{tabular}{|c|c|c|c|c|c|c|}
\hline \multirow{2}{*}{\multicolumn{2}{|c|}{$\begin{array}{l}\text { Reactive power } \\
\quad \text { (Var) }\end{array}$}} & \multicolumn{5}{|c|}{ Active power (W) } \\
\hline & & $-10 \%$ & $-5 \%$ & $0 \%$ & $+5 \%$ & $+10 \%$ \\
\hline \multirow{2}{*}{$-10 \%$} & $\begin{array}{c}\text { Without } \\
\text { Induction } \\
\text { motor }\end{array}$ & $219.07 \mathrm{~V}$ & $204.19 \mathrm{~V}$ & $198.44 \mathrm{~V}$ & $194.65 \mathrm{~V}$ & $188.96 \mathrm{~V}$ \\
\hline & $\begin{array}{c}\text { With } \\
\text { Induction } \\
\text { motor }\end{array}$ & $229.80 \mathrm{~V}$ & $210.11 \mathrm{~V}$ & $202.05 \mathrm{~V}$ & $196.90 \mathrm{~V}$ & $192.13 \mathrm{~V}$ \\
\hline \multirow{2}{*}{$-5 \%$} & $\begin{array}{c}\text { Without } \\
\text { Induction } \\
\text { motor }\end{array}$ & $220.02 \mathrm{~V}$ & $205.48 \mathrm{~V}$ & $199.39 \mathrm{~V}$ & $194.52 \mathrm{~V}$ & $184.11 \mathrm{~V}$ \\
\hline & $\begin{array}{c}\text { With } \\
\text { Induction } \\
\text { motor }\end{array}$ & $221.65 \mathrm{~V}$ & $204.11 \mathrm{~V}$ & $199.30 \mathrm{~V}$ & $197.46 \mathrm{~V}$ & $191.41 \mathrm{~V}$ \\
\hline \multirow{2}{*}{$0 \%$} & $\begin{array}{c}\text { Without } \\
\text { Induction } \\
\text { motor }\end{array}$ & $209.76 \mathrm{~V}$ & $204.25 \mathrm{~V}$ & $199.67 \mathrm{~V}$ & $193.81 \mathrm{~V}$ & $190.52 \mathrm{~V}$ \\
\hline & $\begin{array}{c}\text { With } \\
\text { Induction } \\
\text { motor }\end{array}$ & $215.60 \mathrm{~V}$ & $202.82 \mathrm{~V}$ & $199.45 \mathrm{~V}$ & $194.43 \mathrm{~V}$ & $187.68 \mathrm{~V}$ \\
\hline \multirow{2}{*}{$+5 \%$} & $\begin{array}{c}\text { Without } \\
\text { Induction } \\
\text { motor }\end{array}$ & $218.91 \mathrm{~V}$ & $213.96 \mathrm{~V}$ & $199.63 \mathrm{~V}$ & $193.45 \mathrm{~V}$ & $192.63 \mathrm{~V}$ \\
\hline & $\begin{array}{c}\text { With } \\
\text { Induction } \\
\text { motor }\end{array}$ & $208.77 \mathrm{~V}$ & $204.06 \mathrm{~V}$ & $199.42 \mathrm{~V}$ & $195.68 \mathrm{~V}$ & $190.02 \mathrm{~V}$ \\
\hline \multirow{2}{*}{$+10 \%$} & $\begin{array}{c}\text { Without } \\
\text { Induction } \\
\text { motor }\end{array}$ & $209.32 \mathrm{~V}$ & $203.84 \mathrm{~V}$ & $199.54 \mathrm{~V}$ & $193.48 \mathrm{~V}$ & $187.93 \mathrm{~V}$ \\
\hline & $\begin{array}{c}\text { With } \\
\text { Induction } \\
\text { motor }\end{array}$ & $216.41 \mathrm{~V}$ & $203.37 \mathrm{~V}$ & $200.08 \mathrm{~V}$ & $193.00 \mathrm{~V}$ & $188.19 \mathrm{~V}$ \\
\hline
\end{tabular}

Upper row (Without Induction motor), The lower (With Induction motor)

\section{5. 誘導電動機による電圧維持の検討}

〈5・1〉 配電線停止後の誘導電動機挙動について 誘 導電動機によって電圧值が維持される要因は, 電動機状態 から発電機状態へ変化した可能性が考えられる。そのため, 配電線停止後における誘導電動機の挙動について PCS を連 
系しない(誘導電動機単体) 状態にて検証を行った。なお， 今回検証を行った誘導電動機は, 前章の単独運転継続時間 の計測に用いたものと同一の誘導電動機である。

誘導電動機の構成は, 主巻線及び副巻線にコンデンサを 直列接続した一般的なコンデンサ型誘導電動機である。

配電線停止後の運転状態の確認方法は, 図 2 に示す回路 にて以下の手順に従い, 主卷線電流 $A m$, 副卷線電流 $A s$, コ モン電流 $A c$, 電圧 $V_{1}$ 及び回転数 $N r$ の計測を行った。

(1) 誘導電動機を定常運転状態とし無負荷運転とする。

(2) 並列抵抗負荷 $R$ を $10[\Omega]$ に設定し, $\mathrm{SW}_{\mathrm{r}}$ を投入する。

(3) $\mathrm{t}=0$ のタイミングで開閉器 $\mathrm{SW}_{\mathrm{mg}}$ を開放し, 配電線 が停止した状態を模擬する。

(4) 開閉器 $\mathrm{SW}_{\mathrm{mg}}$ 開放前後の電圧, 電流及び回転数を測 定する。

実験結果は, 図 3 に示すように開閉器 $\mathrm{SW}_{\mathrm{mg}}$ 開放直後に, コモン電流 $A c$ 及び主巻線電流 $A m$ の流れる方向が反転し ていることが確認された。

主卷線電流 $A m$ 及びコモン電流 $A c$ の流れる向きが反転 する現象は, 誘導電動機状態として運転を行っている状態 から, 開閉器 $\mathrm{SW}_{\mathrm{mg}}$ を開放した後に発電機状態に恋化し, 並列に接続された抵抗負荷 $R$ に電力を供給したことによる ものと考えられる。しかし, 実験結果からでは, 誘導電動 機状態から発電機状態に変化したのか不明確である。

そこで, 誘導電動機特有であるすべりに着目し, 分析を

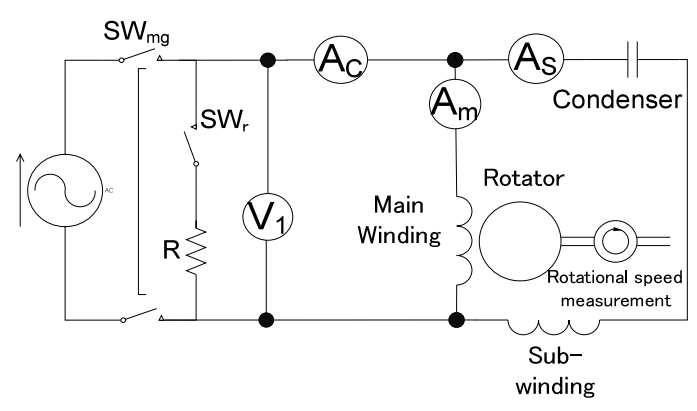

困 2 誘導電動機の回路困

Fig. 2. Circuit chart of induction motor.

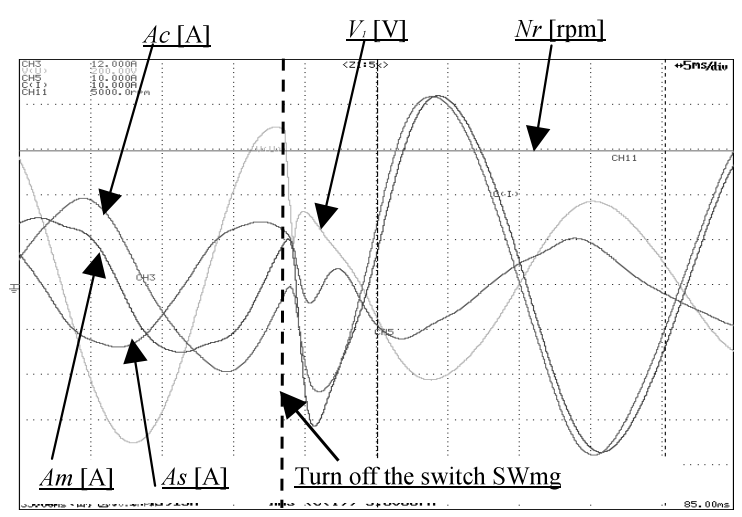

困 3 誘導機負荷の発電状態計測結果

Fig. 3. Power generation state measurement result of inducement machine load.
行うこととした。

$\langle\mathbf{5} \cdot \mathbf{2}\rangle$ 誘導電動機の発電状態分析 誘導電動機は, 通 常すべりが 0 から 1 の範囲で運転されている。そのため, 誘導電動機の同期速度 $N_{S}$ が回転数 $N r$ を越え, すべりが 0 以下で運転されていれば発電機状態に変化していることに なる。

通常すべりは, (1) 式の同期速度と回転数から求められる。

$$
S=\frac{(N s-N)}{N s}
$$

$S:$ すべり [-], $N s$ ：同期速度 [rpm],

$N:$ 回転数 $[\mathrm{rpm}]$

しかし, 同期速度 $[\mathrm{Ns}]$ は，(2) 式に示すように周波数 $f$ の值に合わせて変化する。

$$
N s=\frac{120 f}{p} \text {. }
$$

$N s$ : 同期速度 $[\mathrm{rpm}], f$ : 周波数 $[\mathrm{Hz}]$,

$p:$ 磁極の数

そのため, 配電線停止後の周波数 $F$ は, 一定でないこと から誘導電動機に残る電圧 $V_{1}$ から算出した。

配電線停止後の周波数 $F$ は，(3) 式に示すように電圧 $V_{1}$ が $0[\mathrm{~V}]$ を通過する点をゼロクロス点として求め, そのゼ ロクロス点間の一周期毎の時間 $t[\mathrm{~ms}]$ を(3) 式に代入し算 出した。

$$
F=\frac{1}{t} \text {. }
$$

$$
F: \text { 周波数 }[\mathrm{Hz}], t: \text { ゼロクロス間の時間 }[\mathrm{ms}]
$$

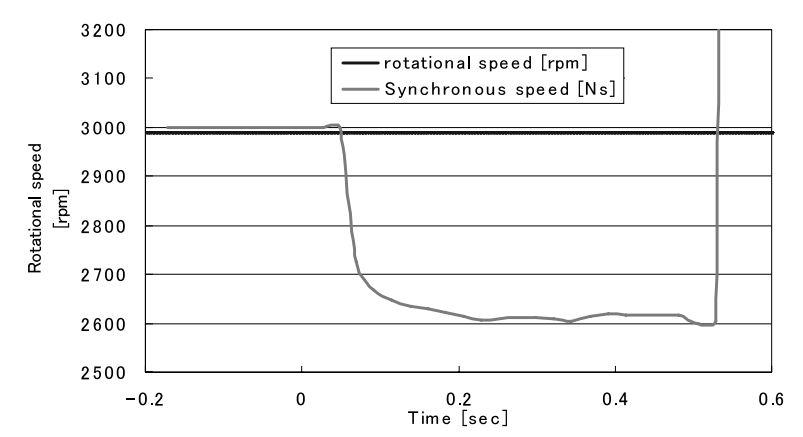

図 4 同期速度の計算結果

Fig. 4. Calculation result of synchronous speed.

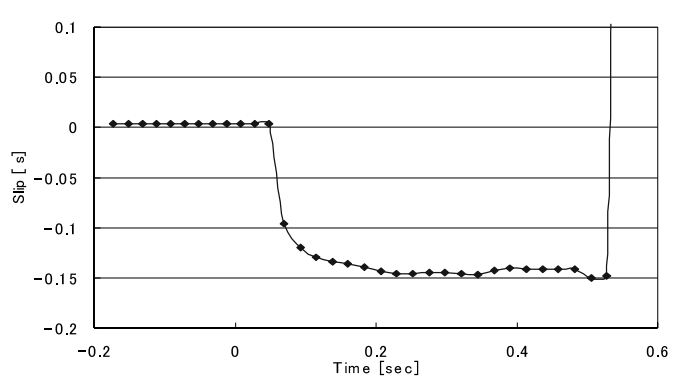

図 5 すべりの算出結果

Fig. 5. Calculation result of slip. 
配電線停止後の同期速度は, 算出した周波数 $f[\mathrm{~Hz}]$ を(2) 式に代入し算出した。算出した同期速度 $N_{S}$ 及び実測回転 数 $N r$ を図 4 に示す。

また, 配電線停止後のすべりについては, 算出した同期速 度 $N_{S}$ 及び実測した回転数 $N r$ を(1) 式に代入し算出した。 すべりの算出結果を図 5 に示す。

$\langle\mathbf{5} \cdot \mathbf{3}\rangle$ 配電線停止後の誘導電動機挙動分析結果 す ベりの算出結果は, 配電線停止後に0以下となり, 発電機 状態へ変化していることが示された。

誘導電動機が発電機状態へと変化する要因は, 切り離さ れた配電線内の周波数が低下し，慣性エネルギーによって 回転子の回転数が維持され同期速度が回転数を下回ったこ とによるものである。

誘導電動機が発電機状態に変化することが明らかになっ たことから, 誘導電動機の発電機状態への变化と単独運転 継続時間との関連について検証を行うこととした。

検証方法は, 〈4·3〉節において行った実験について誘導 電動機が配電線停止後に発電機状態へ变化しているのかを 確認した。単独運転継続時間におけるすべりを表 5 に示す。

誘導電動機は, 表 5 に示すように発電機状態に変化して いる負荷条件では, 表 4 に示した誘導電動機がない状態の 負荷条件と比べて一部の負荷条件 $(\mathrm{P}=-5 \%, \mathrm{Q}=0 \%)$ を 除いて電圧の低下が抑えられていることが確認できた。ま た, 誘導電動機が, 発電機状態に変化していない負荷条件 においても電圧の低下が抑えられている。これらの要因に ついては, 計測結果から誘導電動機の共振による影響のも のと負荷の特性によるものに分類することができる。

負荷条件 $(\mathrm{P}=-10 \%, \mathrm{Q}=0 \%)$ 及び $(\mathrm{P}=-10 \%, \mathrm{Q}=$ $+10 \%)$ は, 約 $7[\mathrm{~V}]$ 程度の電圧差が発生している。これは, 計測結果から誘導電動機の主巻線電流の周波数が大きく変 動し，それに伴い電圧が変化していることが観測されてお り，主巻線が外部に接続された容量性負荷との間に共振を 発生させたことにより電圧が上昇したものと考えられる。 また，それ以外の負荷条件は，静止形の誘導性負荷を用い る場合と誘導電動機を用いて負荷条件を構成する場合に, 消費電力が少ない誘導電動機を用いた負荷条件の方が電圧 低下を抑える結果になったと考えられる。

表 5 単独運転現象継続時間計測時の誘導電動機 の運転状態

Table 5. State of driving of induction motors when measuring it at islanding phenomenon continuance time.

\begin{tabular}{|c|c||c|c|c|c|c|}
\hline \multicolumn{2}{|c||}{} & \multicolumn{5}{|c|}{ Active power [W] } \\
\cline { 2 - 7 } \multicolumn{2}{|c|}{} & $-10 \%$ & $-5 \%$ & $0 \%$ & $+5 \%$ & $+10 \%$ \\
\hline \hline \multirow{4}{*}{$\begin{array}{c}\text { Reactive } \\
\text { power } \\
\text { [var] }\end{array}$} & $-10 \%$ & $\mathrm{~S}<0$ & $\mathrm{~S}<0$ & $\mathrm{~S}<0$ & $\mathrm{~S}<0$ & $\mathrm{~S}<0$ \\
\cline { 2 - 7 } & $-5 \%$ & $\mathrm{~S}<0$ & $\mathrm{~S}>0$ & $\mathrm{~S}<0$ & $\mathrm{~S}<0$ & $\mathrm{~S}<0$ \\
\cline { 2 - 7 } & $+5 \%$ & $\mathrm{~S}>0$ & $\mathrm{~S}<0$ & $\mathrm{~S}>0$ & $\mathrm{~S}>0$ & $\mathrm{~S}>0$ \\
\cline { 2 - 7 } & $+10 \%$ & $\mathrm{~S}>0$ & $\mathrm{~S}>0$ & $\mathrm{~S}>0$ & $\mathrm{~S}>0$ & $\mathrm{~S}>0$ \\
\hline
\end{tabular}

単独運転の継続時間は, 表 2 に示すように誘導電動機が発 電機状態に変化しない負荷条件の単独運転継続時間平均值 が756.2 [ms] であった。また, 誘導電動機が発電機状態に 変化した負荷条件の単独運転継続時間平均值が $761.0[\mathrm{~ms}]$ であった。なお，単独運転が 1 秒以上継続している場合の 負荷条件については, 単独運転時間を 1000 [ms] として平 均值を求めた。

これらの結果から誘導電動機が発電機状態に変化しない 負荷条件に比べ, 電圧低下を抑え単独運転の継続時間が長 くなることが明らかになった。

$\langle\mathbf{5}$ 4 $\rangle$ 誘導電動機の発電機状態による有効電力補償効 果誘導電動機が発電機状態に変化することによる影響 について, 負荷条件 $(\mathrm{P}=+5 \%, \mathrm{Q}=-5 \%)$ を例に分析を 行った。

負荷条件 $(\mathrm{P}=+5 \%, \mathrm{Q}=-5 \%)$ における誘導電動機の 挙動は, 配電線停止直前まで誘導電動機状態として運転を 行い, 配電線停止後から 0.33 秒まで発電機状態となり, 回 転数と同期速度が同期様態のすべり 0 で 0.33 秒から 0.42 秒まで運転を行っている。負荷条件 $(\mathrm{P}=+5 \%, \mathrm{Q}=-5 \%)$ における誘導電動機の回転速度及び同期速度を図 6 に示す。 次に, パワーコンディショナ出力, 誘導性負荷, 容量性 負荷, 抵抗負荷及び誘導電動機における有効及び無効電力 を算出し電力フローとして図 7〜図 10 に示した。

図 7 及び図 8 は, 配電線停止前の誘導電動機状態で運転

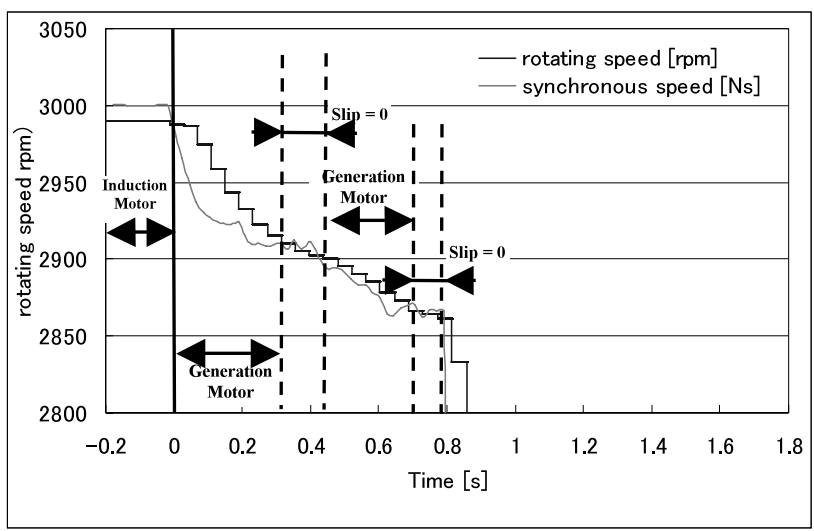

図 6 単独運転実験の回転数及び同期速度

$$
(\mathrm{P}=+5 \%, \mathrm{Q}=-5 \%)
$$

Fig. 6. Rotational speed and synchronous speed of islanding test $(\mathrm{P}=+5 \%, \mathrm{Q}=-5 \%)$.

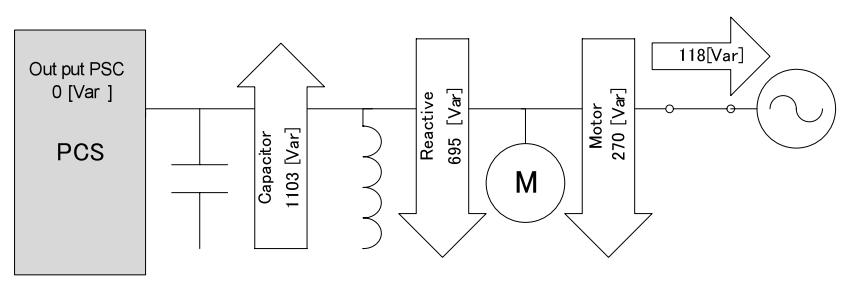

困 7 配電線停止前の無効電力フロー $(\mathrm{P}=+5 \%$, $\mathrm{Q}=-5 \%$ )

Fig. 7. Active power flow in state of induction motors. 


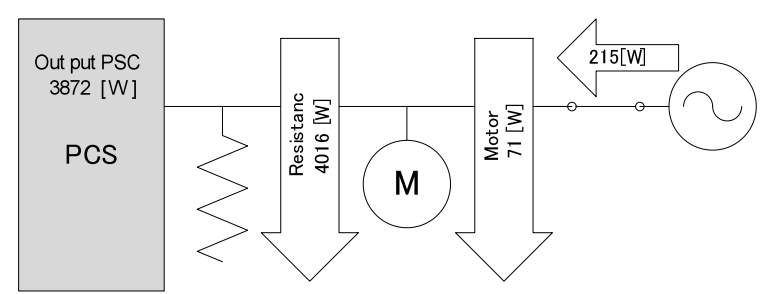

図 8 配電線停止前の有効電力フロー $(\mathrm{P}=+5 \%$, $\mathrm{Q}=-5 \%$

Fig. 8. Reactive power flow in state of induction motors.

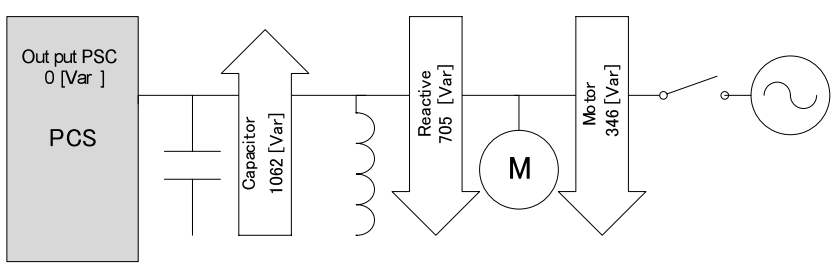

図 9 配電線停止 0.1 後の無効電力フロー

$$
(\mathrm{P}=+5 \%, \mathrm{Q}=-5 \%)
$$

Fig. 9. Reactive power flow in state of electricity generator.

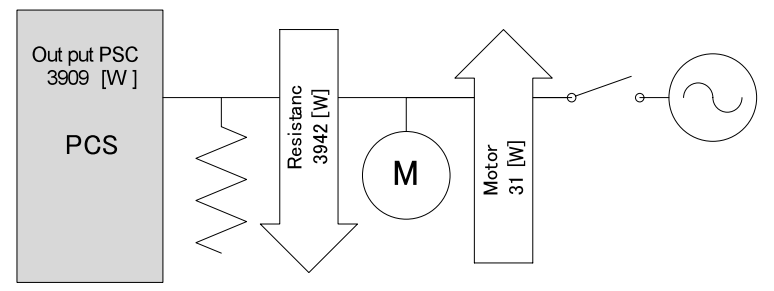

図 10 配電線停止 0.1 後の有効電力フロー

$$
(\mathrm{P}=+5 \%, \mathrm{Q}=-5 \%)
$$

Fig. 10. Active power flow in state of electricity generator.

を行っている時の無効及び有効電力を示した電力フロー困 である。図 9 及び図 10 は，配電線停止 0.1 秒後に誘導電 動機が発電機状態に変化した際の無効及び有効電力を示し た電力フロー図である。図 10 に示す有効電力フロー図は, 抵抗負荷で消費される電力がパワーコンディショナ出力分 では不足していているため，誘導電動機から発生した電力 が補償していることを示している。

\section{6. 単独運転継続時における無効電力相互作用}

$\langle 6 \cdot 1\rangle$ 配電線停止後の誘導電動機定数について 誘 導電動機の無効電力は, 図 7 及び図 9 から配電線が停止し た後に比較的顕著に変化していることが示された。

この要因として，一つは，周波数の変化によるリアク夕 ンスの変化が考えられるが，ここでは，無効電力の変化と 単独運転現象との関連についてより詳細に検証を行うため に，3 章に記載した誘導電動機の定数と周波数 $f$ のとの関 係式を参照し，配電線停止前及び停止 0.3 秒後の誘導電動 機のインダクタンスを算出することとした。

誘導電動機のインダクタンス算出方法は, 誘導電動機に 流れる電流と周波数を用いて (4) 式によって求めた。
表 6 誘導電動機のインダクタンス值変化表

Table 6. Inductance value change table of induction

\begin{tabular}{|c|c|c|c|c|c|c|}
\hline \multirow{2}{*}{\multicolumn{2}{|c|}{$\begin{array}{l}\text { Reactive power } \\
\text { (Var) }\end{array}$}} & \multicolumn{5}{|c|}{ Active power (W) } \\
\hline & & \multirow{2}{*}{$\begin{array}{c}-10 \% \\
114 \mathrm{mH}\end{array}$} & \multirow{2}{*}{$\begin{array}{c}-5 \% \\
114 \mathrm{mH}\end{array}$} & \multirow{2}{*}{$\begin{array}{c}0 \% \\
114 \mathrm{mH}\end{array}$} & \multirow{2}{*}{$\begin{array}{c}+5 \% \\
115 \mathrm{mH}\end{array}$} & \multirow{2}{*}{$\begin{array}{c}+10 \% \\
116 \mathrm{mH}\end{array}$} \\
\hline & $\begin{array}{c}\text { Normal } \\
\text { operation }\end{array}$ & & & & & \\
\hline$-10 \%$ & $\begin{array}{l}0.3 \text { secon } \\
\text {-ds after }\end{array}$ & $44 \mathrm{mH}$ & $54 \mathrm{mH}$ & $84 \mathrm{mH}$ & $90 \mathrm{mH}$ & $84 \mathrm{mH}$ \\
\hline \multirow{2}{*}{$-5 \%$} & $\begin{array}{c}\text { Normal } \\
\text { operation }\end{array}$ & $114 \mathrm{mH}$ & $115 \mathrm{mH}$ & $114 \mathrm{mH}$ & $115 \mathrm{mH}$ & $114 \mathrm{mH}$ \\
\hline & $\begin{array}{l}0.3 \text { secon } \\
\text {-ds after }\end{array}$ & $60 \mathrm{mH}$ & $115 \mathrm{mH}$ & $94 \mathrm{mH}$ & $104 \mathrm{mH}$ & $103 \mathrm{mH}$ \\
\hline \multirow{2}{*}{$0 \%$} & $\begin{array}{c}\text { Normal } \\
\text { operation }\end{array}$ & $114 \mathrm{mH}$ & $114 \mathrm{mH}$ & $114 \mathrm{mH}$ & $115 \mathrm{mH}$ & $116 \mathrm{mH}$ \\
\hline & $\begin{array}{l}0.3 \text { secon } \\
\text {-ds after }\end{array}$ & $50 \mathrm{mH}$ & $95 \mathrm{mH}$ & $117 \mathrm{mH}$ & $128 \mathrm{mH}$ & $116 \mathrm{mH}$ \\
\hline \multirow{2}{*}{$+5 \%$} & $\begin{array}{c}\text { Normal } \\
\text { operation }\end{array}$ & $116 \mathrm{mH}$ & $114 \mathrm{mH}$ & $114 \mathrm{mH}$ & $114 \mathrm{mH}$ & $115 \mathrm{mH}$ \\
\hline & $\begin{array}{l}0.3 \text { secon } \\
\text {-ds after }\end{array}$ & $98 \mathrm{mH}$ & $136 \mathrm{mH}$ & $127 \mathrm{mH}$ & $118 \mathrm{mH}$ & $154 \mathrm{mH}$ \\
\hline \multirow{2}{*}{$+10 \%$} & $\begin{array}{c}\text { Normal } \\
\text { operation }\end{array}$ & $113 \mathrm{mH}$ & $114 \mathrm{mH}$ & $114 \mathrm{mH}$ & $115 \mathrm{mH}$ & $114 \mathrm{mH}$ \\
\hline & $\begin{array}{l}0.3 \text { secon } \\
\text {-ds after }\end{array}$ & $79 \mathrm{mH}$ & $85 \mathrm{mH}$ & $84 \mathrm{mH}$ & $95 \mathrm{mH}$ & $50 \mathrm{mH}$ \\
\hline
\end{tabular}
motors.

Upper row (Before cut out utility line), The lower ( 0.3 seconds after cut out utility line)

$$
L=\frac{Q}{2 \times \pi \times f \times I^{2}}
$$

$L$ :インダクタンス $[\mathrm{H}], Q$ : 誘導電動機の無効電 力 $[\operatorname{Var}], f:$ 誘導電動機の周波数 $[\mathrm{Hz}], I$ : 誘導電 動機の電流 [A]

(4) 式によって算出したインダクタンスを表 6 に示す。 算出結果から，単独運転が継続している負荷条件 $(\mathrm{P}=$ $-10 \%, Q=-5 \%)$ において配電線停止後半分まで值が低下 している。また，同様に負荷条件 $(\mathrm{P}=+10 \%, \mathrm{Q}=+5 \%)$ で は, 1.5 倍程度まで值が増加していることが明らかになった。 なお，無効電力が $+10 \%$ 負荷条件では，インダクタン ス值が小さくなっていることが明らかになった。この原因 は, 表 3 に示したように配電線停止後の周波数が上昇した ことにより誘導電動機内部の主巻線及び副巻線のインダク タンスが低下し, 主巻線電流の周波数が大きく変動してい ることが観測されたため, 主巻線と外部に接続された容量 性負荷との間に共振現象が発生し, 副巻線のインダクタン スのみの值となったためと考えられる。

$\langle\mathbf{6} \cdot 2\rangle$ 単独運転継続時における誘導電動機の無効電力 補償について 配電線停止後の周波数は, 負荷条件の無 効電力がアンバランスの場合, PCS の PLL 制御による力 率一定制御によってその周波数に変化する。しかし, 表 3 に示すように単独運転が継続している負荷条件の周波数は, 配電線停止前と比べても大きく変化していない。そのため, 負荷条件 $(\mathrm{P}=-10 \%, \mathrm{Q}=-5 \%)$ 及び $(\mathrm{P}=+10 \%, \mathrm{Q}=$ $+5 \%)$ における誘導電動機は, 表 6 に示すように変化する 周波数に併せてインダクタンスを変化させながら無効電力 を補償し, その結果, 配電線停止後の周波数の変化を抑制 したものと考えられる。これら無効電力を補償している事 象を電力フローにて検証を行うこととした。 


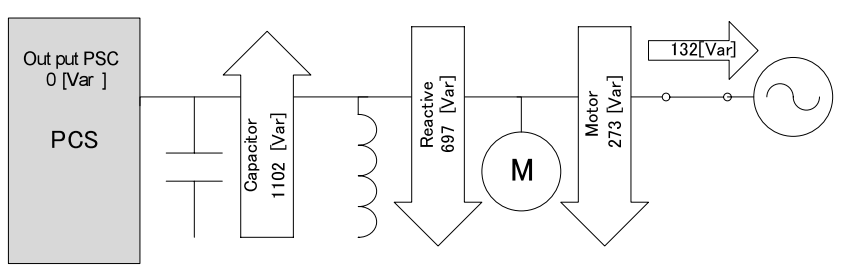

図 11 配電線停止前の無効電力フロー

$(\mathrm{P}=-10 \%, \mathrm{Q}=-5 \%)$

Fig. 11. Reactive power flow in state induction motors.

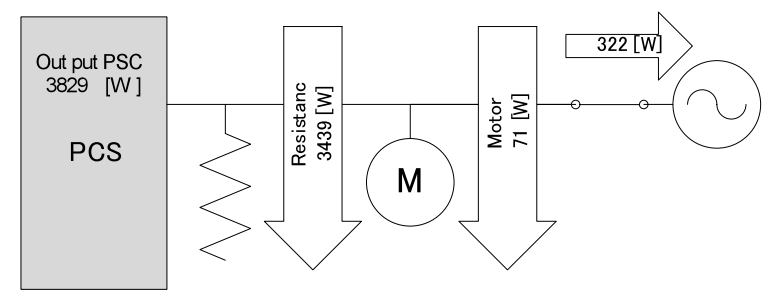

図 12 配電線停止前の有効電力フロー

$$
(\mathrm{P}=-10 \%, \mathrm{Q}=-5 \%)
$$

Fig. 12. Active power flow in state of induction motors.

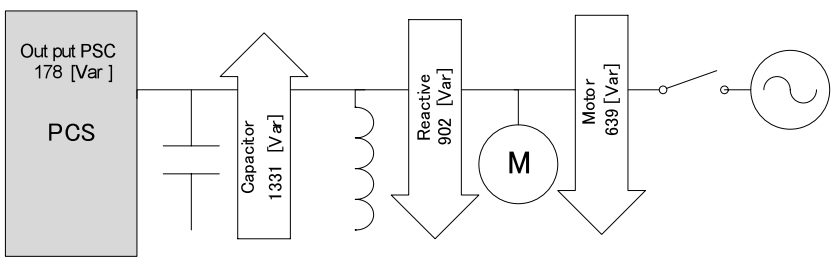

図 13 配電線停止 0.3 秒後の無効電力フロー

$$
(\mathrm{P}=-10 \%, \mathrm{Q}=-5 \%)
$$

Fig. 13. Reactive power flow after 0.3 seconds cut out utility line.

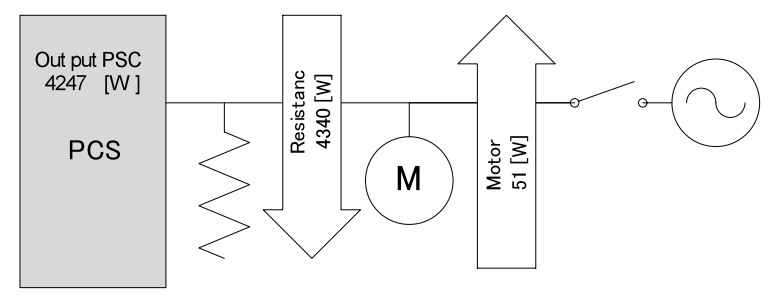

図 14 配電線停止 0.3 秒後の有効電力フロー

$$
(\mathrm{P}=-10 \%, \mathrm{Q}=-5 \%)
$$

Fig. 14. Active power flow after 0.3 seconds after cut out utility line.

\section{〈6・3〉 誘導電動機による無効電力補償の分析について}

誘導電動機が無効電力を補償する事象について負荷条件 $(\mathrm{P}=-10 \%, \mathrm{Q}=-5 \%)$ 及び $(\mathrm{P}=+10 \%, \mathrm{Q}=+5 \%)$ を 例に検証を行った。負荷条件 $(\mathrm{P}=-10 \%, \mathrm{Q}=-5 \%)$ の電 カフローを図 11〜困 14 に示す。図 13 は, 配電線停止 0.3 秒後の無効電力フローを示したものであり，図 11 に示す 配電線停止前の無効電力值と比較した場合には, 2.3 倍まで 無効電力值が顕著に増加し, 単独運転前の無効電力の不平 衡分を補償する方向に変化していることがわかる。

負荷条件 $\mathrm{P}=+10 \%, \mathrm{Q}=+5 \%$ の電力フローを図 15

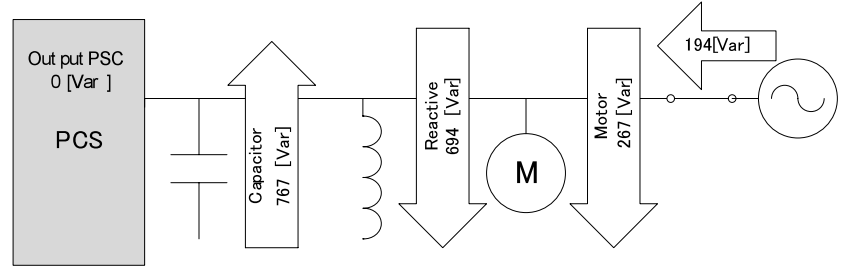

困 15 配電線停止前の無効電力フロー

$$
(\mathrm{P}=+0 \%, \mathrm{Q}=+5 \%)
$$

Fig. 15. Reactive power flow in state of induction motors.

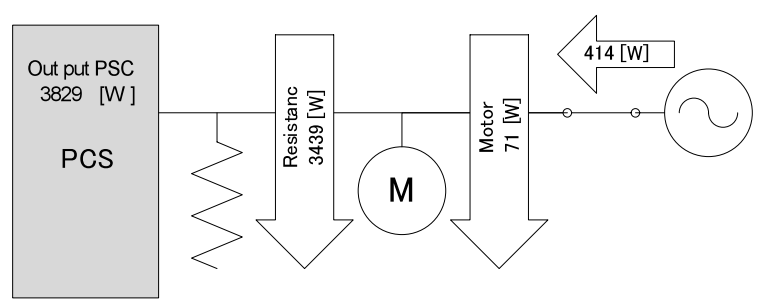

図 16 配電線停止前の有効電力フロー

$$
(\mathrm{P}=+10 \%, \mathrm{Q}=+5 \%)
$$

Fig. 16. Active power flow in state of induction motors.

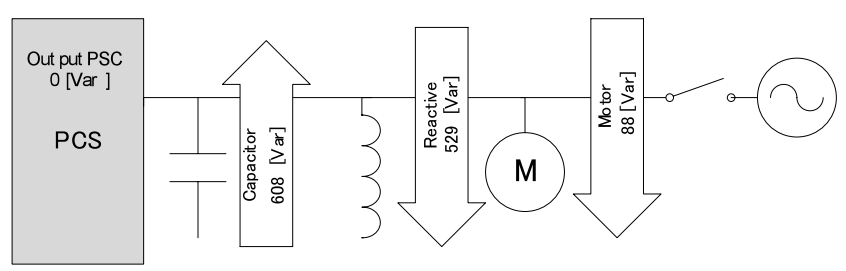

図 17 配電線停止 0.3 秒後の無効電力フロー

$$
(\mathrm{P}=+10 \%, \mathrm{Q}=+5 \%)
$$

Fig. 17. Reactive power flow after 0.3 seconds cut out utility line.

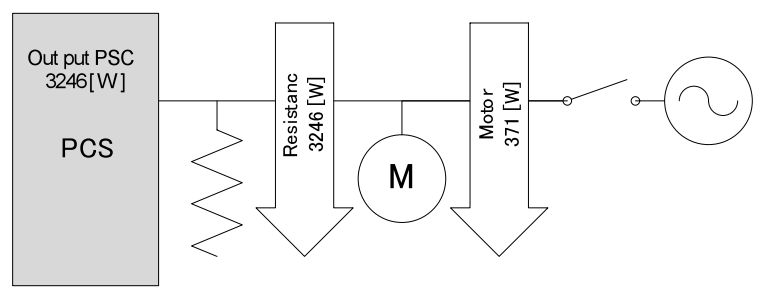

図 18 配電線停止 0.3 秒後の有効電力フロー

$$
(\mathrm{P}=+10 \%, \mathrm{Q}=+5 \%)
$$

Fig. 18. Active power flow after 0.3 seconds after cut out utility line.

困 18 に示す。図 17 は, 配電線停止 0.3 秒後の無効電力フ ローを示したものであり，図 15 に示す配電線停止前の無 効電力量と比較した場合には, 0.33 倍まで無効電力值が顕 著に減少し，単独運転前の無効電力の不平衡分を補償する 方向に変化していることがわかる。

これらの值は，インダクタンス值一定条件の值と比較し て大きく異なる。

これらの結果から誘導電動機は, 配電線停止後において, 周波数が变化する場合は, 定数が変化することから無効電 
力を補償する方向に作用し，単独運転の継続を助長する特 性をもつことが明らかになった。

\section{7. まとめ}

本論文は, 誘導電動機の影響により単独運転継続時間が 長くなることを確認した。

単独運転継続時間が長くなる要因は，配電線停止後に周 波数が低下する場合, 誘導電動機が発電機状態へ変化する ことにより有効電力のアンバランスを補償し, 電圧の変化 を抑制する特性を有することによることを明らかにした。 また，同時に誘導電動機は，配電線停止後において PLL 制 御による力率一定制御によって周波数が変化する場合，そ の周波数の変化を抑制する方向に作用し，単独運転を継続 する特性も有することを明らかにした。

これらにより, 誘導電動機は, 静止形負荷よりも単独運 転現象を発生させやすい負荷であることを明らかにした。

\section{謝 辞}

本研究において，数々の助言を頂いた（財）電力中央研 究所上席研究員小林広武氏に深く感謝いたします。

(平成 19 年 10 月 26 日受付，平成 20 年 2 月 18 日再受付)

\section{文献}

（1）経済産業省原子力安全・保安員編：「電気設備の技術基準」最終改 正平成 18 年 6 月解釈改正

（2）資源エネルギー庁：「電力品質確保に係る系統連系技術要件ガイド ライン」平成 16 年 10 月 1 日資源エネルギー庁

(3)「系統連系規程 JEAC 9701-2006」, 日本電気協会 系統連系専門部会

（4）『サンシャイン計画 新エネルギー・産業技術総合開発機構（NEDO 委託業務成果報告書 (総括版)』として, 平成 3 年度太陽光発電シ ステム実用化技術開発「周辺技術の研究開発」(系統連系制御技術 の実証研究開発)』電力中央研究所, 関西電力

（5）『ニューサンシャイン計画 新エネルギー・産業技術総合開発機棈 （NEDO）委託業務成果報告書』として，平成 5 年度「太陽光発電シ ステム評価技術の研究開発」(周辺技術評価システムの研究開発) 」 電力中央研究所

(6) H. Igarashi: "The tests of islanding have an influence on motor", Proc. of 2005 National Convention Record IEE Japan, No.6-192, p.341-342 (2005) (in Japanese)

五十嵐広宣：「単独運転防止試験時の回転機負荷影響について」, 平 成 17 年電気学会全国大会, No.6-192, p.341-342 (2005)

(7) T. Murakami, K. Kurokawa, H. Kobayashi, and K. Takigawa: "Dynamic characteristic simulation of the utility interconnected PV system-Effect of the induction motor on the detection of islanding-". Proc. of 1998 Annual Conference of Power \& Energy Society, IEE Japan, pp.472-473 (1998) (in Japanese)

村上高徳・黒川浩助・小林広武・滝川 清：「系統連系型太陽光発 電の動特性シミュレーション一誘導機負荷が単独運転検出装置に与 える影響の評価一」, 平成 10 年電気学会電力エネルギー部門大会, pp.472-473 (1998)

(8) H. Igarashi: "About the influence on the difference and the Islanding test of the resonance load and the motor load", IEEJ Trans. PE, Vol.127, No.1, pp.192-199 (2007-1) (in Japanese)

五十嵐広宣：「共振負荷と回転機負荷の相違と単独運転試験への影 響について」, 電学論 B, 127, 1, pp.192-199 (2007-1)

（9）『ニューサンシャイン計画 新エネルギー・産業技術総合開発機構 （NEDO）委託業務成果報告書』として，平成 5 年度太陽光発電シ ステム実用化技術開発太陽光発電利用システム評価技術の研究開発 (周辺技術評価システムの研究開発)」

（10）『ニューサンシャイン計画 新エネルギー・産業技術総合開発機構 （NEDO）委託業務成果報告書』として，平成 6 年度太陽光発電シ ステム実用化技術開発太陽光発電利用システム評価技術の研究開発 (周辺技術評価システムの研究開発)」
（11）『ニューサンシャイン計画 新エネルギー・産業技術総合開発機構 （NEDO）委託業務成果報告書』として, 平成 7 年度 太陽光発電シ ステム実用化技術開発太陽光発電利用システム評価技術の研究開発 (周辺技術評価システムの研究開発)』

(12) 『ニューサンシャイン計画 新エネルギー・産業技術総合開発機構 （NEDO）委託業務成果報告書』として，平成 8 年度 太陽光発電シ ステム実用化技術開発太陽光発電利用システム評価技術の研究開発 (周辺技術評価システムの研究開発)』

（13）『新エネルギー・産業技術総合開発機構（NEDO）委託業務成果報告 書』として, 平成 4 年度 分散型新発電技術実用化実証研究に関する 保護機能等試験方法の確立!

（14）『新エネルギー・産業技術総合開発機構（NEDO）委託業務成果報告 書』として, 平成 5 年度分散型新発電技術実用化実証研究に関する 保護機能等試験方法の確立』

（15）太陽電池発電システム用系統連系保護装置等の試験方法作成：電気 安全環境研究所 (2002-10)

(16) IEC 62116: Test procedure of islanding prevention measures for utilityinterconnected photovoltaic inverters

１7）荻野昭三：誘導電動機の特性,電気書院

五十嵐広 宣 (正員) 1972 年 11 月 19 日生。1993 年 3 月東京

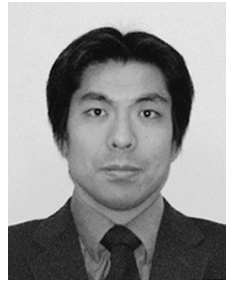
電機大学短期大学電気科卒業。1991 年 4 月（財） 日本電気用品試験所（現，(財) 電気安全環境研 究所）入所。現在，(財) 電気安全環境研究所研 究部先任主査として，太陽光発電システムの系統 連系保護装置の認証業務, 太陽光発電システムの 研究に従事。2004 年 10 月東京農工大学大学院工 学教育部に入学。

佐 藤 孝 則 (非会員) 1973 年 2 月 24 日生。 1996 年 3 月千

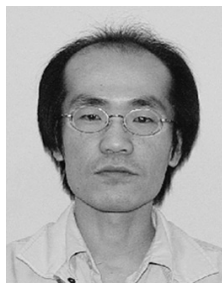
葉大学工学部電気電子工学科卒業。同年 4 月常陽 産業（株）入社。1999 年 5 月同社退社。同年 5 月 (財) 電気安全環境研究所入所, 現在に至る。主 に電力系統の解析業務に従事。

宮 本 和 典 (学生員) 1981 年 6 月 13 日生。 2006 年 3 月東

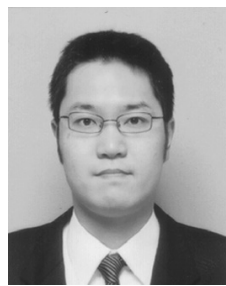
京農工大学工学部電気電子工学科卒業。同年 4 月 東京農工大学院工学府電気電子工学専攻博士前期 課程に進学。現在，太陽光発電システムの単独運 転現象に関する研究に従事。

黒 川 浩 助 （正員） 1942 年 8 月 16 日生。1965 年 3 月早稲

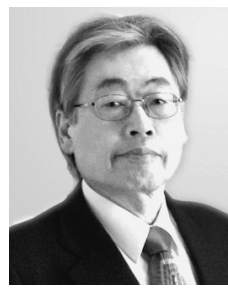
田大学第一理工学部電気工学科卒業。同年 4 月通 商産業省工業技術院電気試験所入所後，高電圧直 流送電の研究に従事。1974 年よりサンシャイン 計画などで太陽エネルギー・太陽光発電の研究。 1996 年 5 月東京農工大学教授に転任。2008 年 4 月より東京工業大学統合研究院特任教授および東 京農工大学特任教授。早稲田大学工学博士。再生 可能エネルギー協議会代表, 国際太陽エネルギー学会理事。IEEE 会員。 